\title{
A argumentação no discurso político de Donald Trump sobre imigração
}

\author{
Argumentation in Donald Trump's \\ political discourse about immigration \\ El argumento en el discurso político \\ de Donald Trump sobre la inmigración
}

\author{
Sandro Bochenek ${ }^{1}$ \\ Alexandre Stein ${ }^{2}$
}

\begin{abstract}
RESUMO: Em 31 de agosto de 2016, o então candidato Donald Trump, em campanha à presidência da República dos Estados Unidos da América, proferiu um discurso sobre imigração ilegal na cidade de Phoenix, no estado do Arizona. Este, que durou aproximadamente $1 \mathrm{~h} 13 \mathrm{~min}$, é considerado o discurso que deu a vitória à Trump nas eleições. Neste estudo, foram analisados trechos desse discurso sob a luz da teoria da argumentação, com o intuito de apontar os recursos e fatores que lhe são inerentes, com base em autores que têm pesquisado a argumentação ao longo dos anos, como Koch (2011), Koch e Travaglia (1999), Oliveira (2002, 2004), entre outros. Concedeu-se atenção especial a três aspectos argumentativos: a intencionalidade, a seleção lexical e as ideologias impregnadas ao discurso. A seleção do corpus foi feita com base na representatividade do gênero discurso político como um gênero essencialmente argumentativo. Os trechos selecionados destacam as principais ideias apresentadas por Trump sobre a referida questão e a forma como o candidato as expõe. Os resultados demonstram o quão eficazes podem ser as estratégias argumentativas utilizadas por políticos no convencimento de eleitores.
\end{abstract}

Palavras-chave: Discurso político. Argumentação. Intencionalidade. Ideologia.

\footnotetext{
${ }^{1}$ Graduado em Letras e Pedagogia, Especialista em Interfaces Linguísticas, Literárias e Culturais, Mestre em Educação pela Unesp - Universidade Estadual Paulista e Doutorando no Programa de Pós-graduação em Estudos da Linguagem pela UEL - Universidade Estadual de Londrina (2016-2019). Professor de Língua Portuguesa no Ctesop - Centro Técnico Educacional Superior do Oeste do Paraná. Contato: bochenek_s@hotmail.com

2 Doutorando no Programa de Pós-graduação em Estudos da Linguagem da Universidade Estadual de Londrina (2016-2019) e professor de Língua Inglesa com experiência no setor público e no setor privado. Contato: alexandrestein02@gmail.com
} 
ABSTRACT: On August $31^{\text {st }}, 2016$, in campaign to the United States presidency, the candidate Donald Trump delivered a speech about illegal immigration in Phoenix, Arizona. The speech, which lasted for about $1 \mathrm{~h} 13 \mathrm{~min}$, is considered the speech that gave Trump the victory on that election process. In this study, we analysed parts of this speech in light of the Theory of Argumentation appointing the resources and factors inherent to this based on authors like Koch (2011), Koch and Travaglia (1999), Oliveira (2002, 2004), among others who have been researching argumentation throughout the years. We focus our analysis on three argumentative aspects: intentionality, lexical selection and the ideologies embedded in the political discourse. We selected this corpus based on the representativeness of the political discourse as a genuinely argumentative genre. The excerpts selected highlight Trump's main ideas on the matter and the way he views the problem. The results show how effective the argumentative strategies used by politicians can be in convincing voters.

Keywords: Political discourse. Argumentation. Intentionality. Ideology.

RESUMEN: En 31 de agosto de 2016, el entonces candidato Donald Trump, en campaña para la presidencia de la República de los Estados Unidos de América, profirió un discurso sobre inmigración ilegal en la ciudad de Phoenix, en la provincia de Arizona. Este, que duró aproximadamente $1 \mathrm{~h} 13 \mathrm{~min}$, es considerado el discurso que dio la victoria a Trump en las elecciones. En este estudio, fueron analizados fragmentos de ese discurso a la luz de la teoría de la argumentación, con el objetivo de apuntar los recursos y factores que les son inherentes, fundamentado en autores que han pesquisado la argumentación a lo largo de los años, como Koch (2011), Koch y Travaglia (1999), Oliveira (2002, 2004), entre otros. Fue concedido atención especial a tres aspectos argumentativos: la intencionalidad; la selección lexical y las ideologías impregnadas al discurso. La selección del corpus fue hecha con base en la representatividad del género discurso político como un género esencialmente argumentativo. Los fragmentos seleccionados destacan las principales ideas presentadas por Trump sobre la señalada cuestión y la forma como el candidato las expone. Los resultados demuestran el cuan eficaces poden ser las estrategias argumentativas utilizadas por políticos para convencer los electores.

Palabras claves: Discurso político. Argumentación. Intencionalidad. Ideología.

\section{Introdução}

O gênero discurso político é, por excelência, argumentativo, pois tem como finalidade convencer o eleitor de que as propostas apresentadas pelo(a) candidato(a) são as melhores e, por esta razão, devem dar a ele(a) o poder de governar aquela cidade, estado ou país. Este estudo pretende demonstrar o quão convincente pode ser esse discurso e quais recursos argumentativos foram usados pelo candidato Donald Trump para conquistar mais apoiadores para as ideias dele. 
O corpus deste trabalho é composto de trechos do discurso de Donald Trump sobre a imigração, realizado na cidade de Phoenix, no estado do Arizona, em 31 de agosto de 2016, a exatos 69 dias da eleição que o elegeu Presidente dos Estados Unidos da América (EUA), contrariando o que as pesquisas de opinião vinham apontando.

Objetiva-se, com este estudo, apontar os operadores argumentativos, as intencionalidades, as escolhas lexicais e outros recursos, linguísticos e retóricos, utilizados pelo candidato para convencer seus eleitores de que suas ideias eram as mais apropriadas para o contexto em que os EUA estão inseridos na atualidade.

O discurso em questão abordou um assunto bastante polêmico entre os norte-americanos - o processo de imigração legal e ilegal -, ou seja, a situação dos imigrantes ilegais que residem naquele país e a entrada de novos. 0 viés adotado por Donald Trump foi atacar as medidas em vigor no governo que o antecedeu e aquelas propostas por sua adversária, a candidata Hillary Clinton, demonstrando os impactos que os imigrantes ilegais causam ao país.

A realização de um estudo sobre esse discurso, que talvez tenha sido o que garantiu a vitória do empresário sobre a candidata democrata, se justifica pela forma como as medidas radicais e polêmicas, com as quais Trump prometeu tratar a questão da imigração nos EUA, repercutiram na mídia nacional e internacional.

As seções que seguem apresentam um histórico sobre a argumentação desde a Antiguidade até os dias de hoje, a fundamentação teórica sobre os fatores e conhecimentos que se relacionam com a argumentação, a seção de análise do corpus e as considerações finais.

\section{Trajetória Histórica da Argumentação}

Esta seção apresenta um retrospecto da argumentação ao longo da história até os dias de hoje e mostra que os gêneros do discurso que se 
instalaram para representar a arte da argumentação desde os primórdios perduram ainda hoje.

\section{Os Primórdios da Argumentação}

Segundo Plantin (1996 apud OLIVEIRA, 2002), o primeiro método de argumentação nasce no século V a.C. com Coráx e Tísias, em Sicília, na Grécia, onde ensinavam retórica para os cidadãos gregos para que pudessem fazer suas 'defesas' perante uma assembleia, quando necessário.

Mais tarde, naquele mesmo século, um grupo de filósofos, pretendendo mudar o foco da educação em Atenas, que visava formar guerreiros e atletas, iniciou ações propondo uma formação mais crítica do aprendiz, cujo novo foco era o homem e a sociedade. Esse grupo de filósofos, então chamado de "mercadores da falsidade", buscava desenvolver a capacidade intelectual dos indivíduos para que fossem capazes de utilizar recursos retóricos para persuadir qualquer um em qualquer situação.

Outro personagem importante da argumentação na Antiguidade foi Górgias, professor de retórica em Atenas, que introduziu a essa disciplina aspectos que contribuíram para que ela se tornasse ainda mais eficaz e convincente. Com o estabelecimento da retórica como uma "arte suprema", surgiram seus desdobramentos, resultando em três gêneros de discurso: o forense, o político e o epidítico (OLIVEIRA, 2002), que serão apresentados mais adiante.

Ao discorrer sobre a argumentação na antiguidade, não se pode deixar de mencionar três outros importantíssimos nomes: Isócrates (436-338 a.C.), Demóstenes (384-323 a.C.) e Aristóteles (383-322 a.C.). O primeiro foi um orador ateniense e "em 392 a.C., fundou em Atenas uma escola de oratória que atraiu muitos alunos e se tornou famosa". O segundo, "considerado o príncipe dos oradores da Antiguidade", criou três estilos de discursos: 1) para as causas privadas; 2) para as causas públicas; e 3) para a assembleia. O terceiro, e mais importante, foi discípulo de Platão e definiu "a retórica como a faculdade de 
descobrir especulativamente o que, em cada caso, é apropriado ao objetivo de persuadir" (OLIVEIRA, 2002, p. 205-206).

A distinção entre os três gêneros de discurso mencionados anteriormente (forense, político e epidítico) foi feita por Aristóteles. Essa denominação, até hoje, é reconhecida e utilizada para classificar os gêneros textuais e discursivos. Também denominados de jurídico, deliberativo e panegírico, esses gêneros têm, respectivamente, seus objetivos assim delimitados: 1) apresentar provas técnicas frente a um tribunal; 2) apresentar problemas relacionados ao povo e à administração das cidades; e 3) apresentar um louvor a alguém diante de uma situação cerimonial.

Com relação ao discurso, propriamente dito, segundo Oliveira (2002) que pode ser dividido em cinco partes: a invenção, a disposição, a elocução, a memorização e a ação. A primeira (invenção) "é um processo criador que consiste em desenvolver as ideias necessárias para nortear um discurso". A segunda (disposição) "é a escolha e a ordenação dos argumentos [...] sempre visando à persuasão". A terceira (elocução) "é a forma de expor os argumentos ou as provas, da maneira mais clara e impressionante para alcançar o objetivo do discurso". A quarta (memória) está relacionada à "técnica de reter as informações necessárias para o desenvolvimento dos argumentos". A quinta e última parte (ação) "é o ato da enunciação oral do discurso englobando recursos vocais como a pausa, entonação, ritmo e recursos corporais como a mímica" (OLIVEIRA, 2002, p. 219-221).

Como se pode notar, a trajetória da argumentação na Antiguidade traz uma clara noção sobre aspectos importantes que se refletem nos estudos sobre esse tema nas épocas posteriores chegando até a atualidade. Esse retrospecto histórico nos permite entender que os estudos sobre a linguagem remontam 2.500 anos. 


\section{A Argumentação Desde a Idade Média até o Século XX}

Na Idade Média, predominou na retórica um aspecto mais ornamental, privilegiando-se, assim, além da elocução, a invenção e a disposição. Alguns nomes de destaque deste período são: Flavio Magno Aurélio Cassiodoro, que dedicou uma pequena parte de sua obra à retórica, adaptando conceitos de memorização e recitação ao uso linguístico dos monges; e São Isidoro, que se dedicou à retórica dando ênfase ao discurso forense e à poética, transformando sua obra em um manual estilístico para a época. Outros dois nomes importantes são: São Jerônimo e Santo Agostinho. O primeiro elaborou a tradução da Bíblia para o latim e era um exímio filósofo. O segundo, considerado um pensador, reconheceu na Bíblia uma retórica de sentidos ambíguos (OLIVEIRA, 2004).

A partir do século XI, a retórica assumiu novos rumos, caracterizando-se pela conciliação entre o pensamento de Aristóteles e de Platão. Um importante representante da retórica no século seguinte foi João de Salisbury, que a concebeu como uma união entre razão e palavra.

Os três gêneros retóricos (judiciário, deliberativo e epidítico), criados na Antiguidade, exerceram certa influência na poesia da Idade Média, com destaque para o terceiro: o gênero cerimonial (ou epidítico), com seu caráter laudatório.

Na Renascença, por sua vez, foi a elocução que teve mais prestígio. Neste período, foram estudados também as figuras de linguagem e os tropos (mudança de sentido das palavras). A partir de 1492, a retórica se torna uma disciplina universitária autônoma em Lisboa e logo se espalha por todo território de Portugal, não mais influenciando somente a gramática e a literatura, mas também outras artes (OLIVEIRA, 2004).

A partir da Idade Contemporânea (séculos XVIII e XIX) a retórica parece se fortalecer. No Brasil, em 1782, é fundada uma escola de Retórica e Poética. Porém, no início do século XIX, a retórica cai em desprestígio, pois o texto passa a ser um pretexto para identificação e denominação das figuras de linguagem. Contudo, no século $X X$, a retórica renasce com força total, pois, "hoje em dia, são a Estilística, a Análise do Discurso, a própria Linguística que retomam, em 
diferentes perspectivas, os problemas que constituíram o objeto da Retórica (DUCROT; TODOROV, 1972, p. 80 apud OLIVEIRA, 2004, p. 115).

Neste mesmo século, surge a Nova Retórica, que tem como alicerce a teoria estilística. Essa última adquire o status de ciência, estabelecendo novos caminhos para a velha retórica, pois privilegiou a análise das funções de linguagem, ou seja, a expressividade.

Entre os nomes de destaque deste período estão: Chaim Perelman e Lucie Olbrechts-Tyteca. Esses autores belgas propõem que a argumentação deve persuadir sem forçar, nem constranger. A adesão do interlocutor ocorre pelas técnicas de persuasão que são inerentes ao próprio discurso.

A trajetória da argumentação culmina nos estudos sobre a enunciação que tem como representante Émile Benveniste. Esse autor consegue extrapolar a dicotomia saussuriana de língua e fala, criando assim, uma Linguística da Enunciação, que privilegia a relação entre interlocutores e discursos.

Avançando nessa trajetória, surge então, na década de 1970, o que hoje se conhece como Semântica Argumentativa, a qual "preocupa-se com as relações entre locutor e alocutário em determinada situação discursiva, direcionando o sentido do texto por meio de uma grande variedade de procedimentos argumentativos" (OLIVEIRA, 2004, p. 123), isto é, considera o papel social da língua na interação do homem com o mundo.

A seção seguinte expõe como a argumentatividade se estabelece e quais as suas implicações e desenvolvimentos.

\section{A Argumentação no Discurso}

Sendo o corpus deste estudo um discurso político, mais especificamente o de Donald Trump sobre imigração ilegal em campanha para a presidência dos EUA, em 2016, acredita-se que é preciso considerar o escopo da argumentação. Para tanto, parte-se de alguns conceitos postos por, entre outros autores, Koch (2011): 
A interação social por intermédio da língua caracteriza-se, fundamentalmente, pela argumentatividade. Como ser dotado de razão e vontade, o homem, constantemente, avalia, julga, critica, isto é, forma juízos de valor. Por outro lado, por meio do discurso - ação verbal dotada de intencionalidade - tenta influir sobre 0 comportamento do outro ou fazer com que compartilhe [...] de suas opiniões. É por esta razão que se pode afirmar que 0 ato de argumentar, isto é, de orientar o discurso no sentido de determinadas conclusões, constitui o ato linguístico fundamental, pois a todo e qualquer discurso subjaz uma ideologia, na acepção mais ampla do termo. A neutralidade é apenas um mito: o discurso que se pretende "neutro" ingênuo contém também uma ideologia - a da sua própria objetividade. (KOCH, 2011, p. 17, grifo nosso)

O trecho de Koch (2011), supracitado, expõe alguns conceitos essenciais para o entendimento do processo de argumentação inerente ao discurso, sobretudo o político. O primeiro que se destaca é a intencionalidade, considerado pela autora como, primordialmente, o gatilho que desencadeia o processo de influenciar o outro a se convencer de que determinada opinião é a mais adequada ou a que deva ser aceita como verdade.

Outro conceito, presente na citação de Koch (2011), que merece destaque é o da ideologia. Quando abordamos o conceito de língua ou linguagem, não podemos deixar de referirmo-nos às ideologias inerentes à esta, pois só se pode influenciar o outro a pensar da forma como se quer, se realmente acreditamos naquilo que discursamos a respeito, ou desejamos que aquilo seja visto como verdade para alcançar nossos objetivos. Isto é, não existe, como a própria autora afirma, discurso neutro, ou seja, desprovido de intencionalidade.

Vale lembrar que a língua desempenha papel determinante nas transmissões, bem como nas imposições de concepções ideológicas, uma vez que, por ser socialmente constituída, a ideologia é inerente a ela, o que a torna, portanto, instrumento por excelência voltado a esse fim.

O funcionamento material da língua determina obrigatoriamente a determinação da materialidade linguística vinculada às suas condições de produção, ou seja, a língua não é mais puro sistema linguístico, que contempla apenas o que é interno a esse sistema. Ao contrário, ela está fortemente vinculada ao social e ao modo de produção dos processos discursivos. E uma língua assim concebida está embebida no ideológico [...]. (INDURSKY, 2011, p. 170). 
Nesse sentido, cabe salientar, ainda, que os discursos adquirem intencionalidades também por meio dos papéis sociais e históricos de seus emissores. No caso do discurso analisado neste artigo, percebe-se que a intencionalidade de vitória - próprio das disputas e dos interesses políticos -, em que os discursos ganham outros significados, tendo em vista a intenção do então candidato à presidência criar no imaginário de seus eleitores a imagem distorcida de um "mal" a ser por ele combatido.

Não se trata, pois, de uma língua asséptica sem sujeito, sem atividade linguageira, sem exterioridade, sem sentidos. Ao contrário: é uma língua que convoca sujeitos historicamente determinados, inscritos em lugares sociais, a partir dos quais enunciam seus discursos. (INDURSKY, 2011, p. 170).

Quando se pensa em argumentação, logo vem à mente termos como convencer e persuadir, os quais são definidos por Perelman (1970 apud KOCH, 2011) de forma bastante clara e sucinta, estabelecendo o que compete a cada um deles:

[...] Enquanto o ato de convencer se dirige unicamente à razão, através de um raciocínio estritamente lógico e por meio de provas objetivas, sendo assim capaz de atingir um "auditório universal", possuindo caráter puramente demonstrativo e atemporal (as conclusões decorrem naturalmente das premissas, como ocorre no raciocínio matemático), o ato de persuadir, por sua vez procura atingir a vontade, o sentimento do(s) interlocutor(es), por meio de argumentos plausíveis ou verossímeis e tem caráter ideológico, subjetivo, temporal dirigindo-se, pois a um "auditório particular": [...]. (PERELMAN, 1970 apud KOCH, 2011, p. 18).

Embora, como definido pelo autor, esses aspectos tenham suas especificidades, é necessário entender que ambos fazem parte do processo argumentativo, já que, para se atingir o objetivo proposto na argumentação, deve-se alcançar tanto os que se convencem pela razão (provas materiais) como os que são persuadidos pela emoção (sentimento, ideologia). Como se pode notar, ao se usar a argumentação, pode-se lançar mão de vários recursos, mas, 
para isso, é preciso estar ciente de que eles existem e podem ser usados a favor de quem está argumentando.

A seção seguinte apresenta os fatores que se relacionam com a argumentação de forma sistematizada a fim de proporcionar uma noção ampla de como eles se articulam e podem interferir no estabelecimento da coerência discursiva.

\section{Fatores que se relacionam com a Argumentação}

Há diversos fatores que podem interferir na inteligibilidade de um texto, oral e escrito, como aceitabilidade, informatividade, intencionalidade, situacionalidade, etc. Pode-se afirmar que todos eles contribuem para que haja coerência textual, possibilitando que se atinja a plenitude semântica desejada. Os estudos do texto estão, em sua maioria, relacionados à coerência. Koch e Travaglia (1999, p. 47) explicam que a coerência "passou a ser vista", no final da década de 1990, "como um princípio de interpretabilidade do texto", ou seja, segundo os autores "tudo que afeta (auxilia, possibilita ou dificulta, impede)" a "interpretação de um texto" está ligado à coerência.

Para Koch e Travaglia (1999, p. 48), o estabelecimento da coerência num texto depende de alguns elementos, entre eles: os linguísticos, o conhecimento de mundo e os fatores pragmáticos e interacionais. A relação entre esses elementos contribui para o que os autores chamam de "construção de um mundo textual". Portanto, é inegável que estes se relacionem com aqueles já citados no início desta seção e que serão abordados detalhadamente mais adiante.

Ainda com relação à coerência, Grice (1975 apud KOCH; TRAVAGLIA, 1999, p. 49) assevera que, na comunicação humana, deve existir o "Princípio da Cooperação [...] do qual decorrem quatro máximas": 1) a da quantidade (informe na medida certa, nem mais, nem menos); 2) a da qualidade (não diga nada que possa ser falso); 3) "a da relação (seja relevante e pertinente)"; e 4) a do modo "(seja claro)". Em suma, esse princípio revela a dependência entre produtor e interlocutor do texto, ideia compartilhada por Charolles (1987 apud KOCH; 
TRAVAGLIA, 1999, p. 49) para quem "a coerência é estreitamente dependente do interpretador que recebe o texto e busca interpretá-lo, usando seus conhecimentos linguísticos, de mundo, etc.".

No que tange aos conhecimentos e fatores necessários para o estabelecimento da coerência, Quadro 1, a seguir, traz observações a esse respeito.

Quadro 1 - Conhecimentos e fatores que interferem no estabelecimento da coerência

\begin{tabular}{|c|c|}
\hline $\begin{array}{l}\text { Conhecimento } \\
\text { linguístico }\end{array}$ & $\begin{array}{l}\text { Domínio sobre o uso de pronomes, nomes pessoais, tempos verbais, palavras } \\
\text { dêiticas, regras de sequenciamento; uso de itens lexicais epistêmicos, } \\
\text { avaliativos, etc. }\end{array}$ \\
\hline $\begin{array}{l}\text { Conhecimento de } \\
\text { mundo }\end{array}$ & $\begin{array}{l}\text { É visto como uma espécie de dicionário enciclopédico do mundo e da cultura } \\
\text { arquivado na memória. Essa forma de conhecimento é dividida em dois tipos: } \\
\text { Conhecimento enciclopédico (background knowledge) que representa tudo o } \\
\text { que se conhece e está arquivado na memória de longo termo. } \\
\text { Conhecimento ativado: (foreground knowledge) que é trazido à memória } \\
\text { presente (operacional e / ou temporário). }\end{array}$ \\
\hline $\begin{array}{l}\text { Conhecimento } \\
\text { partilhado }\end{array}$ & $\begin{array}{l}\text { Trata-se do grau de similaridade entre o conhecimento de mundo do emissor } \\
\text { e do receptor. }\end{array}$ \\
\hline Inferências & $\begin{array}{l}\text { Aquilo que se usa para estabelecer uma relação, não explícita no texto, entre } \\
\text { dois elementos desse texto. É a operação que consiste em suprir conceitos e } \\
\text { relações razoáveis para preencher lacunas (vazios) e descontinuidades em um } \\
\text { mundo textual (BEAUGRANDE; DRESSLER; 1981). }\end{array}$ \\
\hline $\begin{array}{l}\text { Fatores } \\
\text { Pragmáticos }\end{array}$ & $\begin{array}{l}\text { Compreendem os tipos de atos de fala; contexto de situação; interação e } \\
\text { interlocução; força ilocucionária, intenção comunicativa; características e } \\
\text { crenças do produtor e recebedor do texto, etc. }\end{array}$ \\
\hline Situacionalidade & $\begin{array}{l}\text { Refere-se ao conjunto de fatores que tornam um texto relevante para dada } \\
\text { situação de comunicação corrente ou passível de ser reconstituída. }\end{array}$ \\
\hline Intencionalidade & $\begin{array}{l}\text { Diz respeito às intenções dos emissores em produzir uma manifestação } \\
\text { linguística coesiva e coerente, ou ainda efeitos específicos. }\end{array}$ \\
\hline Aceitabilidade & $\begin{array}{l}\text { Tem relação com as atitudes dos receptores de aceitarem a manifestação } \\
\text { linguística como um texto coesivo e coerente, que tenham para eles alguma } \\
\text { utilidade ou relevância. }\end{array}$ \\
\hline Informatividade & $\begin{array}{l}\text { Designa em que medida a informação contida no texto é esperada / não } \\
\text { esperada, previsível / imprevisível. O grau de informatividade de um texto é } \\
\text { medido pela maior ou menor presença dessa relação. }\end{array}$ \\
\hline Focalização & $\begin{array}{l}\text { Está diretamente ligada ao conhecimento de mundo e ao conhecimento } \\
\text { partilhado do emissor e do receptor. Eles vão focalizar sua atenção em } \\
\text { pequena parte do que sabem e acreditam, e a enfatizam. É o que torna a } \\
\text { comunicação eficiente e possível, pois estabelece um campo comum entre } \\
\text { falante/escritor > ouvinte/leitor. }\end{array}$ \\
\hline Intertextualidade & $\begin{array}{l}\text { Compreende as diversas maneiras pelas quais a produção e recepção de dado } \\
\text { texto depende do conhecimento de outros textos, previamente existentes, por } \\
\text { parte dos interlocutores. }\end{array}$ \\
\hline $\begin{array}{l}\text { Relevância } \\
\text { discursiva }\end{array}$ & $\begin{array}{l}\text { Um conjunto de enunciados será relevante se forem interpretáveis como } \\
\text { pertencentes a um mesmo tema / tópico discursivo. }\end{array}$ \\
\hline
\end{tabular}

Fonte: organizado pelos autores com base em Koch e Travaglia (1999). 
Como se pode perceber, são muitos os conhecimentos e fatores que se relacionam com o processo argumentativo, construindo, assim, uma infinidade de possibilidades de análise do texto, sob diversas perspectivas. Os fatores abordados neste estudo estão centrados na intencionalidade, nas escolhas lexicais e nos operadores argumentativos encontrados no discurso sobre imigração, proferido pelo candidato republicano Donald Trump, eleito presidente dos EUA em 8 de novembro de 2016.

Na seção seguinte são apresentados trechos desse discurso e com o intuito de tecer algumas análises considerando-se os aspectos suprarrelacionados e os efeitos de sentido causados por eles.

\section{O Discurso Político e suas Intencionalidades}

Como mencionado anteriormente, o discurso político é, por excelência, um texto argumentativo, muitas vezes bastante eficaz em cumprir seu papel como instrumento de persuasão ou convencimento de que o que está sendo proposto é, de fato, o melhor para aquela sociedade naquele dado momento.

É neste contexto que foram analisados trechos do discurso, de aproximadamente $1 \mathrm{~h} 13 \mathrm{~min}$., pronunciado por Donald Trump num comício em Phoenix-Arizona, no qual ele explora a questão da imigração, assunto bastante delicado para a nação norte-americana frente ao número elevado de imigrantes que a cada ano entram nos EUA, legal ou ilegalmente. Entre os argumentos usados por Trump para convencer os americanos da necessidade de políticas inibitórias à imigração estão os altos índices de crimes cometidos pelos imigrantes ilegais e os impactos, negativos, que este grupo causa à economia daquele país.

O candidato inicia seu discurso afirmando que aquele não seria um discurso de comício por si só, mas a exposição de uma política da qual ele vinha tratando há algum tempo. Essa política referia-se à questão da imigração ilegal.

Sob muitos aplausos, Donald Trump relata que acabara de chegar do México, onde havia se encontrado com o presidente daquele país e segundo ele: 


\section{Excerto 1}

Nós concordamos sobre a importância de se acabar com o fluxo do tráfico de drogas, dinheiro, armas e pessoas através de nossa fronteira, e exterminar os cartéis. (TRANSCRIPT..., 2016, tradução nossa).

We agree on the importance of ending the illegal flow of drugs, cash, guns, and people across our border, and to put the cartels out of business. [...]. (TRANSCRIPT..., 2016).

Embora Trump siga o discurso afirmando que houve contribuições dos mexicanos aos Estados Unidos, o impacto da afirmação acima transcrita, nos faz refletir sobre a visão que o candidato quer passar sobre o México. A escolha lexical utilizada, sobretudo o uso do substantivo 'fluxo' (flow) leva o ouvinte a ter a impressão de que daquele país provêm, em grandes volumes, apenas coisas negativas, se pensarmos que 'fluxo' implica um movimento unilateral.

Dando continuidade, o candidato afirma que a situação da imigração nos EUA é muito pior do que se imagina, mas a mídia não trata do assunto, pois alguns políticos se beneficiam da situação e, usando sua influência, calam a imprensa.

Em outro trecho de seu discurso, ela ainda afirma:

\section{Excerto 2}

Hoje, sobre esse assunto muito complicado e difícil, vocês saberão a verdade. O problema fundamental sobre o sistema de imigração de nosso país é que ele serve aos interesses de doadores muito ricos, ativistas políticos e poderosos, poderosos políticos. (TRANSCRIPT..., 2016, tradução nossa).

Today, on a very complicated and very difficult subject, you will get the truth. The fundamental problem with the immigration system in our country is that it serves the needs of wealthy donors, political activists and powerful, powerful politicians. (TRANSCRIPT..., 2016).

Entre as diversas estratégias de argumentação usadas por Donald Trump, ele sugere que o que ele diz é a "verdade", e por intermédio dele os americanos "saberão a verdade". O peso de sua seleção lexical o torna portador da verdade que tira a venda dos cidadãos daquele país e os faz ver. A repetição do adjetivo "poderosos" (powerfu) pode ser visto como um recurso linguístico que insinua uma condição de submissão daquele povo a um poder (político) que precisa ser desvencilhado.

Como suporte a essa afirmação, Trump complementa dizendo que o que tem sido proposto até então, por políticos que abordam a questão da imigração, 
é a anistia, a abertura das fronteiras e a redução dos salários. Diante disso, ele propõe:

\section{Excerto 3}

[...] se vamos fazer o nosso sistema de imigração funcionar, então temos que estar preparados para falar honestamente e sem medo sobre esse importante e sensível problema. Por exemplo, temos que ouvir as preocupações que os nossos trabalhadores, nossos esquecidos trabalhadores, têm sobre o ritmo recorde de imigração e seus impactos sobre seus empregos, salários, moradia, escola, impostos e condições de vida. (TRANSCRIPT..., 2016..., tradução nossa).

[...] if we're going to make our immigration system work, then we have to be prepared to talk honestly and without fear about these important and very sensitive issues. For instance, we have to listen to the concerns that working people, our forgotten working people, have over the record pace of immigration and its impact on their jobs, wages, housing, schools, tax bills and general living conditions. (TRANSCRIPT..., 2016, texto original)

No excerto acima, vê-se o discurso sendo meticulosamente conduzido para atingir uma classe de eleitores que poderiam definir as eleições: a classe trabalhadora. A utilização do adjetivo "esquecidos" (forgotten), atribuído aos trabalhadores, traz uma carga emotiva com a qual se tenta aproximar o candidato àquela classe. A associação de dois fatores: o aumento de imigrantes no país e os diversos aspectos da vida dos trabalhadores, incita uma intolerância dos últimos com os primeiros.

Outro forte argumento que estimula um comportamento xenófobo dos americanos é a relação que Donald Trump faz entre índices de violência e imigração, estabelecida no trecho transcrito a seguir.

\section{Excerto 4}

Então, há o problema da segurança. Incontáveis e inocentes vidas americanas foram roubadas porque nossos políticos falharam no seu dever de proteger nossas fronteiras e reforçar nossas leis como elas deveriam ser reforçadas. Eu conheci muitos dos ótimos pais que perderam seus filhos para as cidades abrigo e as fronteiras abertas. [...] Incontáveis americanos que morreram recentemente estariam vivos se não fosse pelas políticas de fronteiras abertas desta administração e da administração que tem essa horrível, horrível forma de pensar, chamada Hillary Clinton. (TRANSCRIPT..., 2016, tradução nossa).

Then there is the issue of security. Countless innocent American lives have been stolen because our politicians have failed in their duty to secure our borders and enforce our laws like they have to be enforced. I have met with many of the great parents who lost their children to sanctuary cities and open borders. [...] Countless Americans who have died in recent years would be alive today if not for the open border policies of this administration and the administration that causes this horrible, horrible thought process, called Hillary Clinton.

(TRANSCRIPT..., 2016). 
Analisando o excerto acima, é possível tecer diversas reflexões sobre o quão preconceituosa é a colocação do candidato Trump com relação aos imigrantes. Ele praticamente responsabiliza os imigrantes pelos altos índices de homicídios contra cidadãos norte-americanos, como se esses crimes não fossem praticados também pelos próprios americanos, uns contra os outros. A utilização da voz passiva no trecho "Incontáveis e inocentes vidas americanas foram roubadas $[\ldots]$ " "(Countless innocent American lives have been stolen $[\ldots])$ " deixa implícita (ou explícita), neste contexto, a ideia de que os americanos só são mortos por estrangeiros, o que é passivo de contestação. (TRANSCRIPT..., 2016, tradução nossa).

Outro aspecto que chama a atenção é o uso da expressão "cidades abrigo" (sanctuary cities), provavelmente se referindo às cidades fronteiriças do sul dos Estados Unidos, o que remete à ideia de áreas em que as pessoas vivem como refugiados. E a afirmação de que "muitos dos ótimos pais que perderam seus filhos para as cidades abrigo" "(many of the great parents who lost their children to sanctuary cities)", faz parecer que os moradores (estrangeiros) destas cidades são todos criminosos, caracterizando um processo de generalização bastante importante para alcançar o objetivo de convencer os cidadãos norte-americanos do perigo que os mexicanos representam. (TRANSCRIPT..., 2016, tradução nossa).

Retomando um pouco dos conceitos apresentados anteriormente sobre o processo de argumentação, pode-se afirmar que Trump está fazendo uso dos conceitos de convencer e persuadir, postulados por Perelman (1970 apud KOCH, 2011). Pois, com as afirmações colocadas acima e as transcritas a seguir, ele apela tanto para o caráter emocional (persuasão) quanto para o racional (convencimento). 


\section{Excerto 5}

O presidente Obama e a Hillary Clinton têm se envolvido com um não cumprimento das obrigações legais por entregarem a segurança dos americanos às fronteiras abertas. Vocês sabem disto. $\mathrm{O}$ presidente Obama e a Hillary Clinton apoiam as cidades abrigo. Eles apoiam o prender e soltar de pessoas na fronteira. Eles apoiam os vistos expirados. Eles apoiam a soltura de perigosos, perigosos, perigosos criminosos. Eles apoiam a anistia executiva inconstitucional. Hillary Clinton tem alegado que dará anistia nos seus 100 primeiros dias de governo [...]. Além disso, ela promete uma imigração descontrolada e de pessoas desqualificadas que continua a reduzir os empregos e os salários dos trabalhadores americanos [...]. Isso inclui seu plano de trazer 620.000 novos refugiados da Síria e daquela região num curto período de tempo. (TRANSCRIPT..., 2016, tradução nossa).

President Obama and Hillary Clinton have engaged in gross dereliction of duty by surrendering the safety of the American people to open borders [...]. You know it. President Obama and Hillary Clinton support sanctuary cities. They support catch and release on the border. They support visa overstays. They support the release of dangerous, dangerous, dangerous, criminals from detention. And, they support unconstitutional executive amnesty. Hillary Clinton has pledged amnesty in her first 100 days, [...]. On top of that, she promises uncontrolled, low-skilled immigration that continues to reduce jobs and wages for American workers, [...]. This includes her plan to bring in 620,000 new refugees from Syria and that region over a short period of time. (TRANSCRIPT..., 2016).

Alguns recursos linguísticos utilizados nesse pequeno trecho chama atenção, por exemplo, a repetição dos nomes "Obama" em dois momentos e, "Hillary Clinton", por três vezes, com a função de associar as políticas de imigração descritas a esses nomes, com o intuito de causar nos ouvintes um repúdio às pessoas citadas e às políticas por elas praticadas.

Como se pode notar, por intermédio dos argumentos expostos, o então candidato à presidência dos Estados Unidos convence e persuade seus eleitores, pelo menos os presentes naquele comício, produzindo uma retórica que apresenta dados pertinentes à vida dos cidadãos daquele país, produzindo efeitos e reações por meio de sua enunciação carregada de intenções. Como apresentado por Koch (2011):

O conceito de intenção é, assim, fundamental para uma concepção de linguagem como atividade convencional: toda atividade de interpretação presente no cotidiano da linguagem fundamenta-se na suposição de que quem fala tem certas intenções ao comunicar-se. Compreender uma enunciação é, nesse sentido, apreender essas intenções. (KOCH, 2011, p. 22).

Mesmo sabendo que aqueles que se faziam presentes naquele comício e os que o assistiam pela televisão apoiavam suas ideias, a pergunta que fica é: 
com que força os atos "ilocucionários"3 e "perlocucionários"4 atingem os interlocutores de um discurso, já que o referido candidato acabou se elegendo? Com base em reflexões como estas pode-se tecer considerações sobre o quão poderoso pode ser um discurso que pretende convencer e persuadir aqueles que nem sempre conseguem "apreender essas intenções" (KOCH, 2011, p. 22).

\section{Considerações Finais}

Nos cinco trechos do discurso político de Donald Trump sobre a imigração, aqui apresentados, percebe-se que diversos recursos argumentativos foram utilizados pelo candidato com a finalidade de convencer e persuadir os eleitores de que suas propostas eram as mais adequadas para o momento delicado vivenciado pelos Estados Unidos, com relação à imigração ilegal.

Entre esses recursos pode-se elencar as escolhas lexicais por meio das quais ele expressa sua intencionalidade e ideologias e afirmar que, talvez, este seja um elemento fundamental para que se atinja uma argumentatividade eficaz nesse gênero.

Mesmo em meio a muitas críticas, de americanos e pessoas do mundo todo, Donald Trump se elegeu presidente dos Estados Unidos, para um mandato de, pelo menos, quatro anos. O que permite concluir desse acontecimento é que discursos podem realmente ganhar eleições, mesmo causando a surpresa daqueles que, ao perceberem as estratégias de argumentação do candidato não se deixaram convencer.

Como bem apresenta Koch (2011, p. 23) "[...] A distinção entre dizer e mostrar permite penetrar nas relações entre linguagem, homem e mundo: é sob esse aspecto que se torna possível falar de ideologia na linguagem." No caso apresentado neste estudo pode-se ver que aqueles que detêm a técnica discursiva podem levar suas ideologias a serem incutidas nas mentes daqueles

\footnotetext{
${ }^{3}$ Atos ilocucionários: dizem respeito a 'força' com que os enunciados são produzidos $(\mathrm{KOCH}$, 2011, p. 18).

${ }^{4}$ Atos perlocucionários: dizem respeito aos efeitos visados pelo uso da linguagem, entre os quais os de convencer e persuadir (KOCH, 2011, p. 18).
} 
que nem sempre estão atentos para perceber as nuances dos enunciados e suas intencionalidades.

\section{Referências}

INDURSKY, Freda. Estudos da linguagem: a leitura sob diferentes olhares teóricos. In: TFOUNI, Leda Verdiani (org.). Letramento, escrita e leitura: questões contemporâneas. Campinas: Mercado das Letras, 2011.

KOCH, Ingedore Grunfeld Villaça. Argumentação e linguagem. 13. ed. São Paulo: Cortez, 2011.

KOCH, Ingedore Grunfeld Villaça; TRAVAGLIA, Luiz Carlos. Texto e coerência. 6. ed. São Paulo: Cortez, 1999.

OLIVEIRA, Esther Gomes. A argumentação na antiguidade. Signum: Estudos da Linguagem, Londrina, v. 5, n. 1, p. 201-214, dez. 2002.

OLIVEIRA, Esther Gomes. Argumentação: da idade média ao século XX. Signum: Estudos da Linguagem, Londrina, v. 7, n. 2, p. 109-131, dez. 2004.

TRANSCRIPT of Donald Trump's immigration speech. The New York Times, New York, NY, 1 Sep. 2016. Politics. Disponível em: https://www.nytimes. com/2016/09/02/us/politics/transcript-trump-immigration-speech.html. Acesso em: 11 jun. 2019. 